\title{
All-Inclusive Sustainability? The Sustainable Development Goals at the Antwerp Port Authority Compact Case
}

\author{
Lars Moratis \\ Professor of Sustainable Business \\ Antwerp Management School
}

Boogkeers 5 / BE-2000 Antwerpen, Belgium

E-mail: lars.moratis@ams.ac.be

Received: February 13, 2019

Accepted: March 20, 2019 Published: June 24, 2019

doi:10.5296/csbm.v6i1.14971 URL: http://dx.doi.org/10.5296/csbm.v6il.14971

\begin{abstract}
Launched in 2015, the Sustainable Development Goals (SDGs) represent an authorative global agenda to achieve sustainability. Many organizations have been adopting the SDG and linking it to their sustainability strategies. When the Antwerp Port Authority (APA) adopted the SDGs, it initially focused on five out of these 17 goals. After consulting its stakeholders, APA concluded that its initial choice should be replaced by a choice for focusing on the entire set of SDGs. Since 2017, the SDGs constitute the overarching framework for APA's sustainability strategy. This brief case aims to enable students to explore and reflect on business organizational approaches towards the SDGs.
\end{abstract}

Keywords: sustainability, sustainable development, Sustainable Development Goals, stakeholders, stakeholder consultation, materiality, maritime sector 


\section{The Agendas of Sustainable Development}

Sustainable development is generally seen as a precondition for sustainaning human and non-human life on the long-term. Defined as "development that meets the needs of the present without compromising the ability of future generations to meet their own needs" (WCED, 1987) it calls on all actors in societies worldwide to contribute to sustainability. Being an influential actor, business has taken many sustainability initiatives over the past years, from motivations ranging from moral obligation and securing its license to operate to developing sustainability-driven business cases and and spurring innovation. Following the United Nations Millennium Summit and ending in 2015, the Millennium Development Goals (MDGs) represented eight international development goals that encouraged business to take a large role in developing living standards. Late former United Nations Secretary General Kofi Annan said in 2005 that "the MDGs can be met by 2015 - but only if all involved break with business as usual and dramatically accelerate and scale up action now" (UNDP, 2005: 5). However, the MDG agenda has been far from realized: while areas such as education and extreme poverty have shown progress, targets on safe drinking water and undernourishment have actually witnessed slowdown, leading to negative overall numbers for incremental lives improved (MacArthur \& Rasmussen, 2017).

\section{The Sustainable Development Goals and the Antwerp Port Authority}

When the Sustainable Development Goals (SDGs) supplanted the MDGs and where adopted in 2015 by more than 150 countries, it did not take the Antwerp Port Authority (APA) in Belgium long to decide to adopt them. The Port of Antwerp is the second largest port in Europe, after Rotterdam in the Netherlands, comprising over 900 companies and 142,000 employes. With the goal of enabling the Port of Antwerp to function efficiently and effectively, APA's activities include, among many other things, lockkeeping, supervising quays, dispatching tug boat captains, accounting, and operating harbour cranes. Employing nearly 1,600 people, APA is one of the dominant economic players and employers in the Antwerp region. It has a strong international orientation, and having had its sustainability strategy in place for several years, the APA felt the SDGs could provide an overarching framework that would even better align its sustainability approach with global stakeholder expectations and the sustainability challenges that are most pressing in the world.

The SDGs, part of the 2030 Agenda for Sustainable Development that is a global action plan to improve the lives of people, ecological quality, and prosperity, represent a set of 17 goals, include eradicating poverty, ending hunger, ensuring gender equality, taking action to protect life below water, and promoting peace and justice (Exhibit 1). These 17 global goals for sustainable development consist of no less than 169 targets and 330 individual indicators to monitor them. Reflecting the inclusiveness of the agenda, according to the United Nations, the SDGs are integrated and indivisible by their nature (United Nations, 2015). 

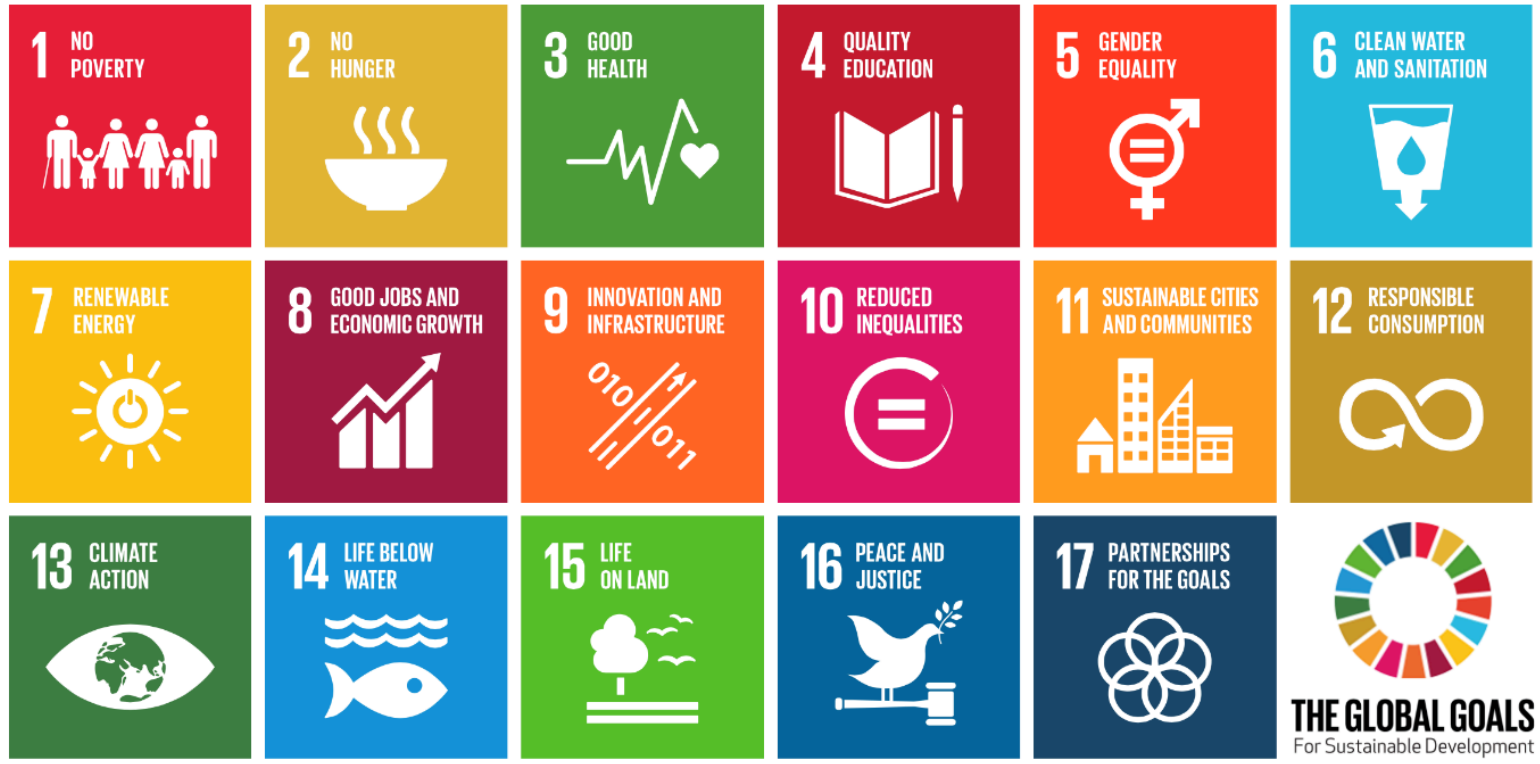

Exhibit 1. The sustainable development goals

\section{Focusing on All-Inclusive}

In an initial effort to link its material sustainability topics to the SDG agenda and since 'focusing' on the entire set of SDGs seemed impractical in terms of the operationalization of its sustainability strategy, APA chose to focus on five SDGs: SDG 7 (Affordable and clean energy), SDG 8 (Decent work and economic growth), SDG 9 (Industry, innovation and infrastructure), SDG 13 (Climate action), and SDG 17 (Partnerships for the goals). With stakeholder dialogue being an existing practice at the organization, APA subsequently engaged in a stakeholder consultation process to map the views of its stakeholders on the 2030 Agenda in general and discuss the SDGs selected by the organization to focus on. An important insight from this process was that stakeholders indicated that the selection of SDGs made by APA was inadequate as it only recognized part of the roles played in local and regional society by APA and the impacts organizations such as APA had on people, planet, and the economy. There appeared to be many sub-goals in which the Port of Antwerp has a role to play.

In addition, stakeholders felt that narrowing down of the SDGs did not reflect the spirit of the indivisibility of the SDGs and thus ignored their interconnectedness. For instance, it was pointed out by stakeholders that the APA had a crucial role in developing SDG 11 (Sustainable cities and communities), which has an effect on SDG 15 (Life on land), SDG 13 (Climate action) and SDG 3 (Good health), which, in turn, have an effect on SDG 8 (Good jobs and economic growth).

As a result of consulting stakeholders on its SDG engagement, APA decided to abandon its initial focus on five SDGs and replaced it with an engagement to all 17 SDGs. The 17 SDGs are now an integral part of APA's sustainability's strategy and function as the main 


\section{Macrothink \\ Case Studies in Business and Management \\ ISSN 2333-3324 \\ 2019, Vol. 6, No. 1}

guidelines for transitioning to a more sustainable port as mirrored in its 2030-2050 vision. As APA's 2017 sustainability reports states: "In its vision the port community sees the SDGs as one and indivisible, and thus as pointing the way for a sustainable port that aims to remain the leader in creation of sustainable added value" (Antwerp Port Authority, 2017, p. 4).

However, an important question arises from this situation: does focusing on the entire set of 17 SDGs not represent a contradictio in terminis?

\section{References}

Antwerp Port Authority. (2017). Sustainability report 2017. Antwerp: Antwerp Port Authority.

MacArthur, J., \& Rasmussen, K. (2017). How successful were the Millennium Development Goals? Accessed on 21 September at: https://www.brookings.edu/blog/future-development/2017/01/11/how-successful-were-the-mi llennium-development-goals/.

UNDP. (2005). Human Development Report 2005 - International cooperation at a crossroads: Aid, trade and security in an unequal world. New York: UNDP.

United Nations. (2015). Transforming our world: The 2030 Agenda for Sustainable Development. Resolution A/RES/70/1. New York: United Nations.

WCED. (1987). Report of the World Commission on Environment and Development: Our Common Future. Oxford: Oxford University Press.

\section{Copyrights}

Copyright for this article is retained by the author(s), with first publication rights granted to the journal.

This is an open-access article distributed under the terms and conditions of the Creative Commons Attribution license (http://creativecommons.org/licenses/by/4.0/). 